\title{
CORPUS Corpus
}

Archivos virtuales de la alteridad americana

Vol 3, No $1 \mid 2013$

Enero / Junio 2013

\section{El nacimiento del Brasil: Revisión de un paradigma historiográfico}

The birth of Brazil: Review of a historiographical paradigm

João Pacheco de Oliveira

Traductor: Andrea Roca

\section{OpenEdition}

Journals

Edición electrónica

URL: http://journals.openedition.org/corpusarchivos/192

DOI: 10.4000/corpusarchivos. 192

ISSN: $1853-8037$

Editor

Diego Escolar

\section{Referencia electrónica}

João Pacheco de Oliveira, «El nacimiento del Brasil: Revisión de un paradigma historiográfico »,

Corpus [En línea], Vol 3, No 1 | 2013, Publicado el 19 diciembre 2013, consultado el 20 abril 2019. URL : http://journals.openedition.org/corpusarchivos/192 ; DOI : 10.4000/corpusarchivos.192

Este documento fue generado automáticamente el 20 abril 2019.

Licencia Creative Commons: Atribución-NoComercial 2.5 Argentina (CC BY-NC 2.5 AR) 


\section{El nacimiento del Brasil: Revisión de un paradigma historiográfico}

The birth of Brazil: Review of a historiographical paradigm

João Pacheco de Oliveira

Tradución : Andrea Roca

\section{NOTA DEL EDITOR}

Fecha de recepción del original: 08-03-2013

Fecha de aceptación para publicación: 24-04-2013

Traducción: Andrea Roca (LACED/MN/UFRJ).

\section{Introducción}

1 Quisiera comenzar este texto con una observación general que entristece a los etnólogos. Cuando en exposiciones, videos, libros didácticos, debates públicos y entrevistas presentamos bellísimos ejemplos de la riqueza y complejidad de las organizaciones socioculturales de los pueblos indígenas, de sus cosmologías, de sus valores éticos y estéticos elementos continuamente presentes en nuestras etnografías-, raramente somos escuchados. Nuestros datos e interpretaciones no permanecen en el pensamiento de las personas porque contradicen una narrativa que les es completamente antagónica, asentada en prejuicios naturalizados por usos sociales, rutinas e instituciones.

2 Intentar introducir datos e imágenes nuevos en una estructura narrativa que les es completamente inmune y adversa, incapaz de incluir o resignificar cualquier información que se oponga a sus postulados, es un esfuerzo con resultados bastante limitados. Los objetos con los cuales trabaja la Antropología son fenómenos históricos y contienen fuertes componentes políticos. Por consiguiente, tanto las formas de representación sobre la historia como la dimensión implícita de los prejuicios y tomas de partido de los oyentes 
pueden estimular una fuerte resistencia hacia nuestros argumentos, dificultando sobremanera la incorporación de las conclusiones a las que llegamos.

3 A pesar de que las grandes interpretaciones sobre el Brasil propuestas durante el siglo XX entran en conflicto entre sí con relación a diversos aspectos, sus narrativas divergen muy poco en lo que atañe a los indígenas, así como en las apreciaciones sobre su contribución en la formación de la nacionalidad. Las diferencias debidas a distintas formaciones disciplinarias $\mathrm{y} / \mathrm{o}$ enfoques teóricos producen variaciones superficiales de poca relevancia que no afectan los presupuestos subyacentes, los cuales cristalizan en un sistema de verdades que constituye la parte invisible y no verbalizada de ese iceberg. Incluso cuando eventualmente las posturas éticas o políticas de esas personas se distancian del conservadurismo, tales verdades raramente son revisadas porque entran en conflicto con otras certezas y porque aseguran el punto de equilibrio de su interpretación de la historia como una totalidad.

4 En el Brasil, la base primaria sobre la cual descansan estas interpretaciones y las verdades fundacionales acerca de la relación entre la nación y sus poblaciones autóctonas fueron enunciadas hace más de 150 años, tanto por la construcción intencional y sistemática de la primera historia del Brasil, escrita por Francisco Adolfo de Varnhagen (1854), como por las directivas que Carl Friedrich Philipp von Martius recomendó para dicha tarea en un concurso promocionado en 1840 por el Instituto Histórico e Geográfico Brasileiro (en adelante, IHGB), donde su memoria fue la vencedora. Aunque el pueblo brasileño era descrito como el resultado del cruce entre tres razas (blancos, negros e indios), no existía ninguna igualdad entre ellas y el Brasil fue siempre imaginado como un proyecto y una creación portuguesa. De tal forma, la preocupación central fue destacar los elementos de continuidad con las instituciones, doctrinas y significados encontrados en la vida lusitana. La complejidad del tejido social de la colonia, la importancia de los pactos y estrategias locales, la diversidad del potencial económico de las diferentes regiones, los reiterados esfuerzos de colonización emprendidos por otras potencias europeas, las constantes guerras contra los indígenas y las permanentes protestas y rebeliones nativas y populares han sido fenómenos minimizados en su significación contemporánea, descritos con ligereza y analizados muy superficialmente. El eje narrativo consistía en presentar al Brasil como una herencia portuguesa, explicando de esta forma su unidad geográfica y política así como la forma de gobierno que acompañó al proceso de la independencia y de la construcción de las instituciones nacionales.

6 Lo que quisiera proponer aquí es otra lectura de los episodios iniciales de la historia del Brasil, inspirada en las perspectivas y estrategias de las poblaciones autóctonas -quienes fueron las primeras colectividades sometidas en la construcción de la historia nacional. Se trata de "escribir la historia a contrapelo"1, haciendo estallar una estructura narrativa que continúa siendo redactada exclusivamente bajo la perspectiva de los vencedores.

Esta aún era reproducida recurrentemente en pleno siglo XX; ya no estaba focalizada en las grandes figuras o en una historia política comprometida con el establishment, sino en un análisis de las formas económicas, de las relaciones de producción y de las redes internacionales. Sin embargo, de poco sirve adoptar una ideología liberal o socialista, o reemplazar portugueses por ingleses y norteamericanos, si ciertas interpretaciones sobre el Brasil continúan naturalizando los prejuicios contra sus poblaciones autóctonas e ignoran totalmente las experiencias fundacionales de la creación de la colonia en la América Portuguesa. Fue justamente en dicho contexto en donde se establecieron instituciones y prácticas sociales cruciales para explicar el proceso de formación nacional 
en el siglo XIX, así como para entender la ocupación de los espacios interiores (fronteras económicas) en el siglo XX.

8 Existen algunos trabajos previos importantes cuya propuesta fue exorcizar los prejuicios sobre los indígenas, intentando cambiar las valoraciones de la narrativa convencional y portuguesa ${ }^{2}$. Historiadores e intelectuales de otras especialidades pudieron acceder a contribuciones muy ricas basadas en el relativismo y en el reconocimiento académico del discurso antropológico, en las cuales se argumentaba que el sentido de las acciones atribuidas a los indígenas necesitaba considerar sus propias referencias culturales ${ }^{3}$.

Es indispensable realizar una crítica radical de las categorías y los esquemas analíticos que todavía son ampliamente aplicados para comprender la presencia indígena en la formación del Brasil. El texto presentado a continuación no deriva del descubrimiento de nuevas fuentes documentales, sino de una operación historiográfica (De Certeau, 1982) que propone una relectura diferente de las fuentes ya conocidas, intentando articular los resultados de las investigaciones recientes en historia y antropología con las paradojas y dilemas que los movimientos indígenas presentan actualmente al Estado y a la sociedad brasileña.

De tal forma, este artículo propone revisar críticamente categorías coloniales, imágenes e interpretaciones reificadas sobre los indios y el Brasil, con la intención de hacer estallar una estructura narrativa ${ }^{4}$ que hoy en día obstaculiza la investigación científica, y que tampoco ayuda a comprender los actuales y complejos desafíos para la ciudadanía presentados por el aumento del protagonismo indígena ${ }^{5}$.

\section{El paradigma evolucionista}

11 La narrativa convencional sobre la historia del Brasil contiene dos aspectos estilísticos vinculados al paradigma evolucionista que merecen ser comentados. El primero es el papel del azar. Hacia fines del siglo XV, los relatos sobre las condiciones precarias y aventureras de la navegación ayudaron a crear expectativas bastante equivocadas sobre el descubrimiento del Brasil y la relación de los europeos con las poblaciones autóctonas. Por extensión metonímica, muchas veces el encuentro fue descrito como obra del azar, algo casi accidental y fortuito, contado siempre con un algo de ironía y nonsense. Bajo la perspectiva del evolucionismo, la fuente de la dinámica social es exterior a la conciencia y totalmente independiente de la voluntad de los hombres; por lo tanto, el sentido de las acciones humanas debe ser engendrado a posteriori. No habría por qué preocuparse demasiado con las concepciones de la época, ni tampoco con la existencia de alternativas históricas.

12 Aquí entra el segundo aspecto. La búsqueda de una racionalidad lleva a localizar a los personajes y a los eventos concretos dentro de un proceso mayor, el de la expansión del mundo europeo en el continente americano, integrando una narrativa más abarcadora, supuestamente inexorable y de sentido unívoco. Lo casual desemboca en una fatalidad que anula completamente a los agentes históricos, sin que ni siquiera sea necesario justificarlos o absolverlos. Todo coincide para crear la certeza sobre la condición efímera de aquel encuentro, así como sobre la poca importancia de los indígenas en la conformación del mundo colonial que habrá de instaurarse en la llamada América Portuguesa. 

"ciclo", que tendrá como función describir la diversidad de formas económicas y sociales registradas en la historia. Sin embargo, para utilizar dicha noción será necesario colocarla en el interior de un proceso abstracto, acumulativo y ascendente, de sentido teleológico. tales como el pau-brasil ${ }^{6}$, el azúcar, el cuero, las drogas del sertão $0^{7}$, las minas, el café y el látex. Más tarde, le seguirán las distintas fases de la industrialización... El interés del estudioso en cada una de esas formas converge hacia el momento en que una de ellas penetra una zona de intensa visibilidad y se transforma en el modo de producción dominante, ofreciendo fuentes extensas y variadas al investigador. Fuera de este momento de "apogeo" los relatos resultan siempre simplificadores, colocando en un lugar secundario a todos los hechos que no "encajan" perfectamente en la lógica de la forma económica dominante.

En esa narrativa hay un lugar y un momento claramente atribuidos al indígena: ambos son anteriores al Brasil. Si antes de la llegada de los portugueses los indígenas eran los detentores exclusivos de los recursos naturales, bajo tal perspectiva la narrativa sobre ellos debía ser localizada preferentemente antes de la colonización. Una vez iniciada, los indígenas sólo podrían ser concebidos como flores que inevitablemente se marchitan y mueren, siendo necesario registrarlos antes de que desaparezcan. La superioridad tecnológica y militar de los colonizadores, las violencias y las epidemias podrían explicar su extinción.

De nada sirve aplicar nuevas teorías ni proponer una reforma terminológica si el "sistema de verdades" en el que descansa la narrativa convencional no fuere objeto de una revisión crítica. El término "descubrimiento" es equívoco e inaplicable, pero su reemplazo por eufemismos tales como "encuentro de culturas" o "encuentro de civilizaciones" puede resultar inocuo si, al mismo tiempo, dejan de cuestionarse las reglas sintácticas y los presupuestos del discurso colonial. Un antidiscurso (tal como hablar de "invasión") tendrá el mismo destino si no es dirigido hacia una crítica profunda de las certezas y actitudes naturalizadas en la narrativa habitual.

17 Es imprescindible destacar que esa narrativa - que aquí combatimos- no fue en modo alguno contemporánea a los hechos del siglo XVI, sino una producción del siglo XIX; no se desarrolló dentro del universo renacentista o en el mundo colonial, sino en el contexto del evolucionismo, sobre todo durante el llamado Segundo Imperio (Cezar, 1999). Desde aquel entonces reina como una verdad absoluta entre pensadores de derecha o de izquierda, historiadores, sociólogos y filósofos.

18 En su famosa carta, Pero Vaz de Caminha -escribano de la primera flota que llegó al Brasil- no hablaba de descubrimiento sino del "hallazgo"8 (término que no excluye la intencionalidad); tampoco consideraba a los autóctonos como peligrosos, improductivos o incapaces. Incluso con intereses completamente opuestos a los de los indígenas, los cronistas del siglo XVI no dejaron de registrar la extensión numérica y la diversidad de los autóctonos. En sus relatos, administradores, misioneros y particulares dedicaron muchas de sus páginas a las diversas "naciones de gentíos" que encontraron, dejando clarísimo que la colonia sería inviable sin establecer un modus vivendi con ellos, ya fuera para catequizarlos o para exterminarlos.

19 Casi un siglo y medio después del "hallazgo" del Brasil, al volver a Europa tras un largo período en Pernambuco, el Príncipe de Orange, Mauricio de Nassau, escribía a la Compañía de las Indias Occidentales afirmando que el destino de la colonia dependería 
fundamentalmente "de las relaciones que los administradores consigan establecer con los nativos" (Nassau, 1906). Tal apreciación no surgía de la imaginación de un navegante quinientista al encontrar una tierra lejana poblada por criaturas nunca vistas por los europeos, sino por el administrador de la mayor área de plantation esclavista de América y principal proveedora de azúcar en el mercado europeo, cuyas riquezas y potencialidades eran objeto de planes y disputas entre las metrópolis coloniales.

El reconocimiento de la importancia de la presencia indígena en la colonia no era una particularidad de los holandeses: también lo podemos encontrar en los minuciosos trabajos de cartógrafos portugueses, donde se torna evidente que durante la primera mitad del siglo XVII los colonizadores solo controlaban la franja del litoral. El mapa de Albernaz de 1631 muestra claramente el control territorial ejercido por "naciones indígenas", algunas de ellas con nombres genéricos (como los "tapuias"), otras mejor identificadas (como los potiguaras, tupinambás o tupiniquins, entre otros).

Atlas do Estado do Brasil, de João Teixeira Albernaz (llamado "o velho"), 1631.

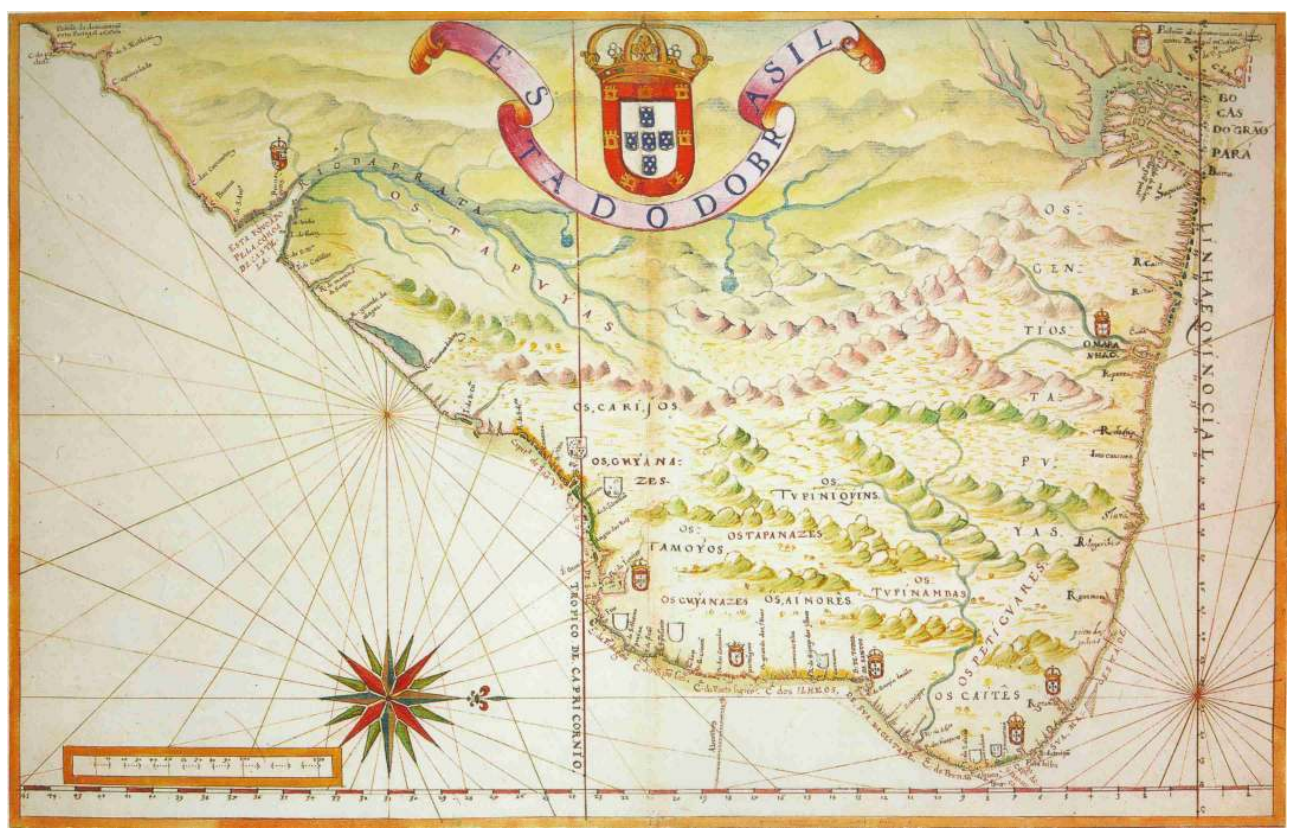

Esa narrativa convencional será estructurada recién durante el Segundo Imperio, mientras el proyecto de nación era elaborado a partir de los debates sobre la inmigración y el fin de la esclavitud, atribuyendo a los indígenas la única función de ser el símbolo de la tierra; contará con un autor (la monumental historia general de Varnhagen) y con una institución que la respaldará (el IHGB, posteriormente con sus sedes provinciales), internalizándose en el pensamiento de la elite y de los sectores populares 9 .

\section{El régimen de las factorías}

Durante la primera mitad del siglo XVI las áreas costeras de América meridional eran intensamente disputadas por portugueses y franceses (excepcionalmente, también se encontraban algunos españoles). Ganar la simpatía de los nativos y contar con su colaboración era la principal preocupación de ambos lados. 
El régimen de las factorías designa la primera situación histórica ${ }^{10}$ en donde las poblaciones autóctonas y los europeos son colocados regularmente en interacción. La producción se centra primordialmente en el pau-brasil y la economía se basa en el trueque; la atención está focalizada en el comercio, siendo el territorio objeto de disputas. La relación entre colonizadores y colonizados no es dualista sino bipartita, e incluye cuatro elementos: los portugueses, sus enemigos franceses, los indígenas que se alían a los portugueses y los indígenas que se alían a los franceses. El conflicto entre los europeos se apropia de los conflictos entre los propios tupis, superponiéndose y apareciendo frente a algunas "naciones de gentíos" con un código que les era familiar y lleno de significaciones.

El registro de narrativas y representaciones simpáticas sobre los indígenas del Brasil derivó de dicho contexto, configurándose un primer régimen de memoria sobre esas poblaciones ${ }^{11}$. La primera representación gráfica de los indígenas que tuvo lugar en Portugal fue a través de la Epifanía del altar mayor de la catedral de Viseu, obra pintada por Vasco Fernandes (también llamado "Grão Vasco") alrededor de 1505, en donde uno de los Reyes Magos aparece bajo la forma de uno de los tupiniquins que asistieron a la misa celebrada por Fray Henrique de Coimbra. La representación positiva ${ }^{12}$ sobre los nativos también se reflejará en la cartografía, sobre todo en el mapa titulado "Terra Brasilis" (1519), atribuido a Lopo Homem junto a Pedro y Jorge Reinel. Dicho mapa -notable por el grado de detalle del litoral, que registra el nombre de 146 accidentes geográficos a lo largo de la costa - presenta una imagen colorida y radiante tanto de los indígenas como de la naturaleza, de acuerdo con la llamada "Tierra de los Papagayos"13.

Epifania, altar-mor de la catedral de Viseu, de Vasco Fernandes, llamado Grão Vasco, alrededor 1505

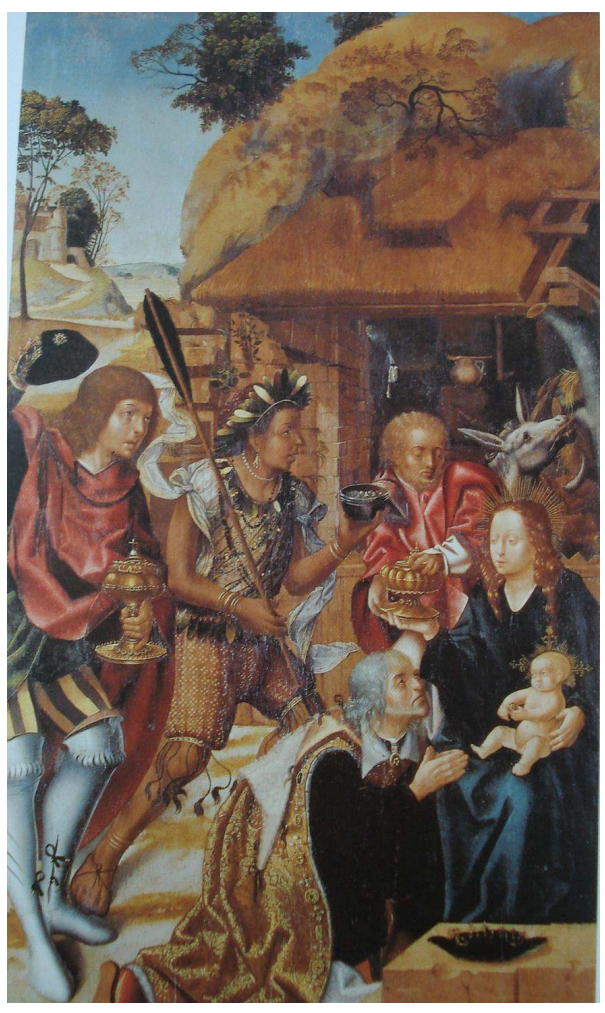


Terra Brasilis, de Lopo Homem junto a Pedro y Jorge Reinel, 1519

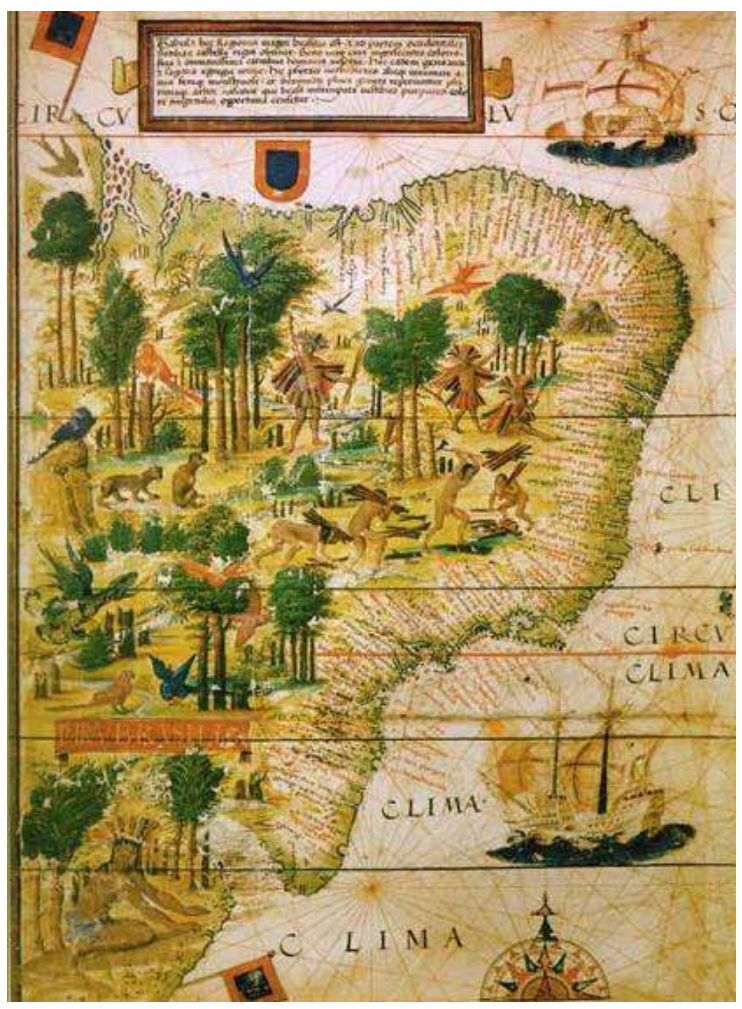

Las representaciones sobre los indígenas y el Brasil no fueron producidas únicamente por el imperio portugués: reflejando su presencia en las costas atlánticas, existen relatos e iconografía realizados también por franceses. Inclusive dentro del propio contexto europeo, la presencia de jefes indígenas aliados otorgaba prestigio a los monarcas, quienes los trataban muy bien; exhibidos en las cortes francesa y portuguesa, estos jefes indígenas eran llamados "reyes"14. 
Medaillon du Roi Sauvage, Eglise de Saint-Jacques.Dieppe, 1535

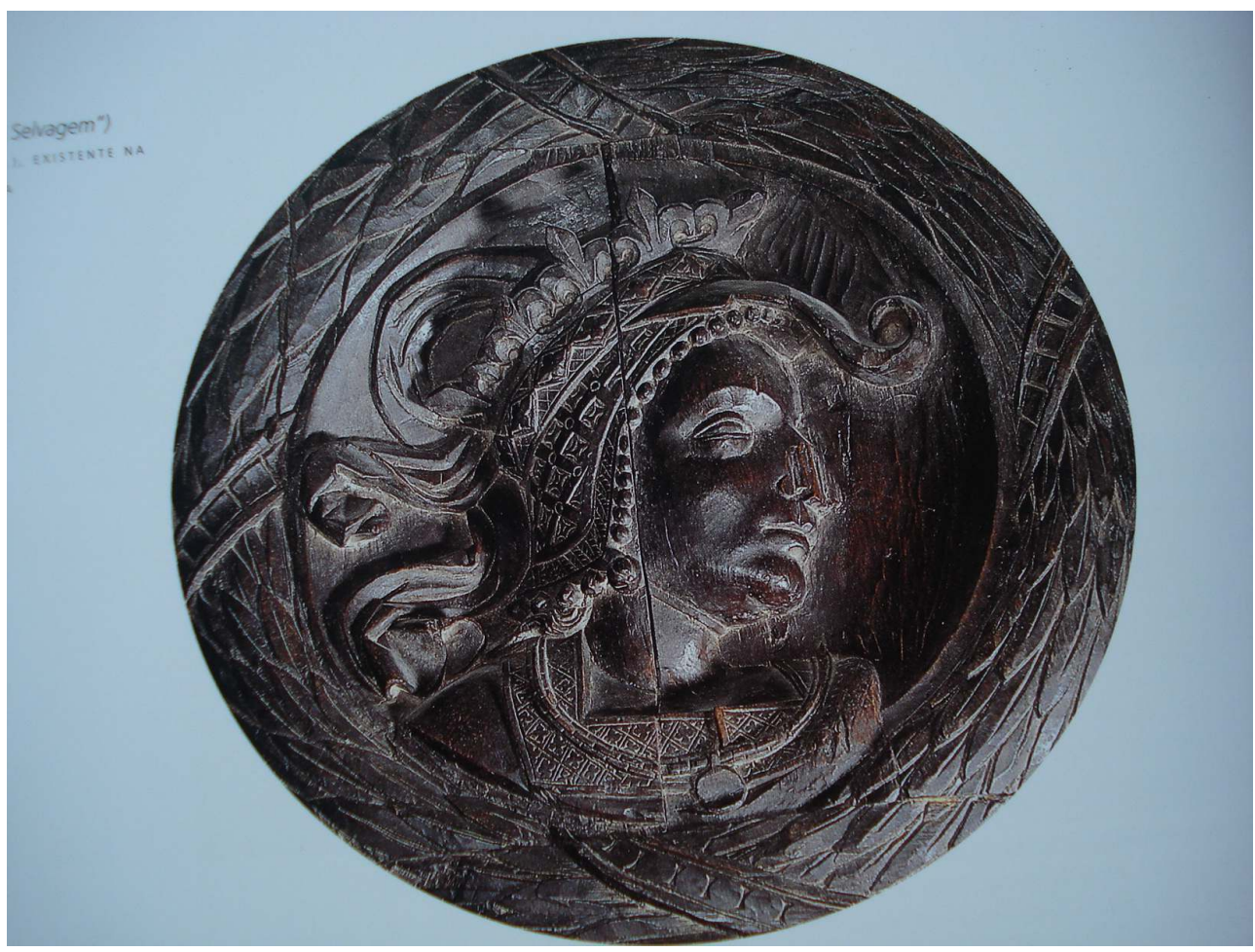

Frise des sauvages, Église de Saint-Jacques.Dieppe, 1530

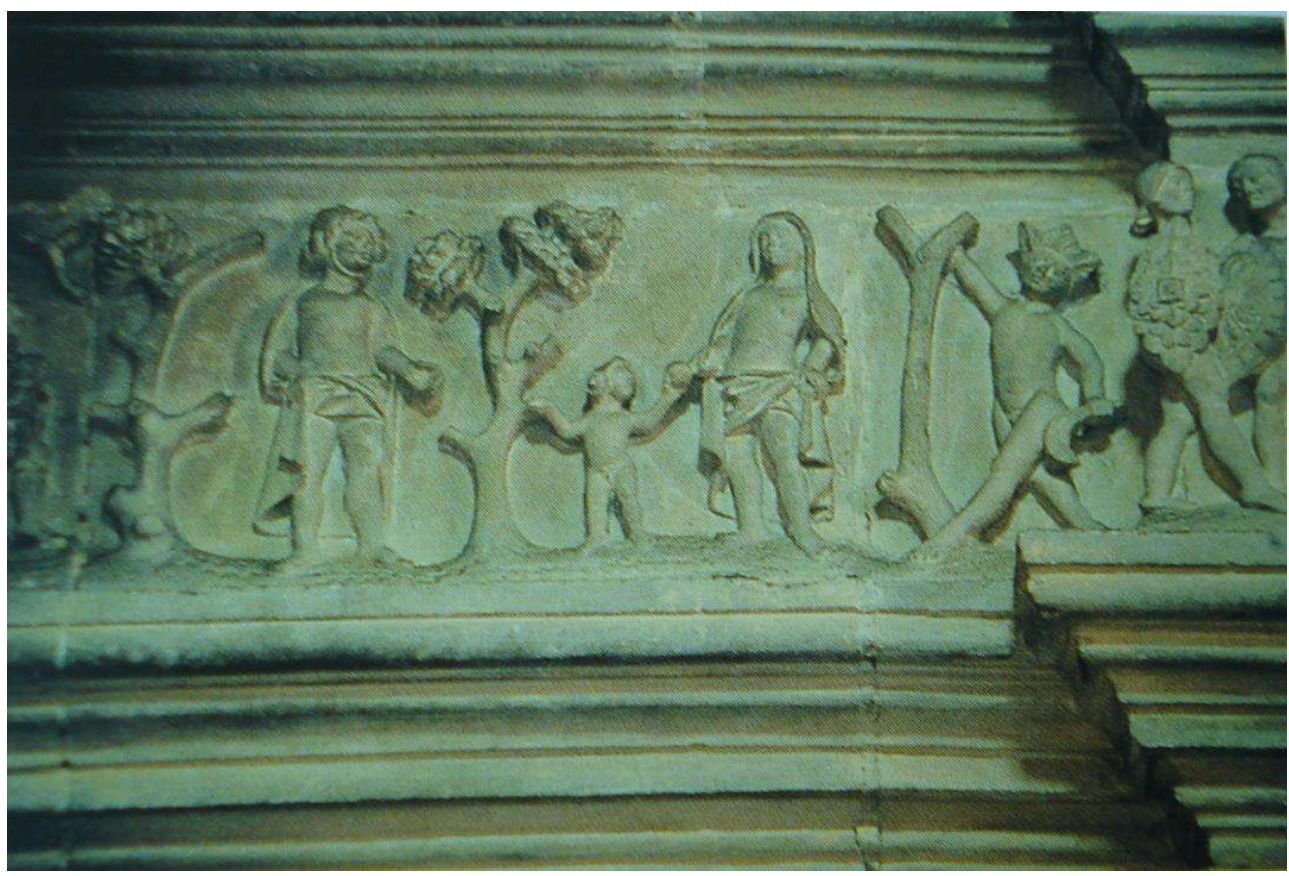




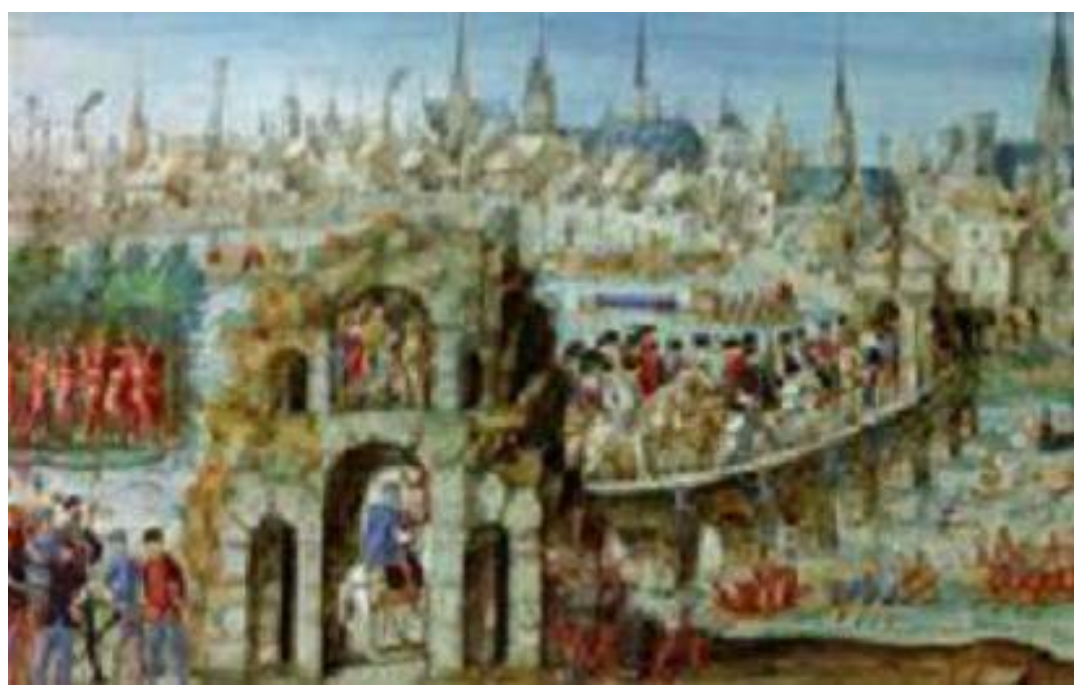
Brasil" era bastante reducida: Igarassu, Olinda, Ilhéus, Porto Seguro, Santa Cruz (hoy Cabrália), Vitória (Espírito Santo), São Vicente (reedificada en otra localidad) y Santos. La mayoría de esos poblados se encontraba frecuentemente sitiada por indígenas hostiles, sin condiciones de expandir (o incluso de conservar) sus núcleos iniciales (véase entre otros Cortesão, 1969). Por su parte, los franceses mantenían un comercio regular y algunas alianzas con indígenas en Rio de Janeiro, en la isla de Itamaracá, en Paraíba y en Sergipe. 
proyecto civilizador. A través de la Regiduría de 17/12/1548 otorgada a Tomé de Souza, primer gobernador general, es posible visualizar con nitidez el cambio de postura de la Corona portuguesa en relación al Brasil. Ya no se trataba de aprovechar los jardines del paraíso, sino de tomar las medidas necesarias para ganar una guerra (que estaba siendo perdida) contra los indígenas y sus aliados franceses.

Las orientaciones iban en el sentido de ampliar el poder defensivo de los núcleos ya existentes, fortificando las villas y los poblados. Los propios ingenios y haciendas debían ser dotados de estructuras defensivas, tales como torres y fuertes. Todos los pobladores que poseían una casa, tierras o embarcaciones debían contar con armamento propio. Era rigurosamente prohibido vender a los "gentíos" cualquier tipo de arma defensiva u ofensiva (arcabuces, espingardas, pólvora y municiones, ballestas, lanzas, espadas o puñales). Para dirigirse hacia los sertões ${ }^{17}$ a través de los ríos fue autorizada la construcción de embarcaciones a remo equipadas con piezas de artillería, proporcionadas por la Hacienda Real (Couto, 1995, p. 233).

31 La Regiduría recomendaba que los indios aliados recibieran un buen tratamiento, prohibiendo -bajo pena de azote- que los moradores fueran a las aldeas ${ }^{18}$ para reclutar trabajadores o para comerciar sin autorización expresa del gobernador. Al reprimir los abusos, la Corona pretendía evitar disturbios y revueltas por parte de los indígenas, así como evitar que estos pudieran inclinarse hacia el lado de los franceses.

El Rey enfatizaba la importancia de la conversión al catolicismo de la población nativa. No obstante, quienes se opusieran al dominio portugués serían alineados bajo el crimen de "traición", para el cual la Regiduría prescribía un tratamiento muy duro. Los tupinambás aparecen explícitamente citados, recomendando que todos aquellos que se rebelaran contra los portugueses fueran "castigados con mucho rigor (...) destruyéndoles sus aldeas y poblados, matando y aprisionando una parte de ellos, la parte que os parezca suficiente como castigo y ejemplo". En este texto ya encontramos una aplicación de la figura jurídica de la "guerra justa".

A diferencia de las Indias, en donde la presencia portuguesa era discontinua y convivía con instituciones bastante heterogéneas, el objetivo básico en el Brasil pasó a ser el control territorial, creando una unidad entre núcleos dispersos y vulnerables, e implantando las instituciones políticas europeas. Lo que el Rey tenía en la mira era establecer la plena y total sumisión de la población autóctona, declarando la guerra a quienes no aceptaran el dominio portugués y dejando a los franceses sin ningún respaldo para sus iniciativas.

La versión consagrada de la historia no describe los hechos de esta manera. Acompañando las fuentes oficiales de la época -que reflexionaban en términos diplomáticos y en función del Tratado de Tordesillas-, los franceses son calificados como "invasores", mientras que los indígenas que establecieron alianzas con ellos fueron clasificados como "traidores". Paradójicamente, este historicismo ingenuo y extremo fue asociado a un "presentismo" del siglo XIX, bastante etnocéntrico, que no reconocía ningún protagonismo indígena en la relación con las naciones europeas. Al enunciar los objetivos de la actuación portuguesa predomina una lectura unilateral de las fuentes, estableciendo como rationalia la expulsión de los franceses. Preferentemente, el lugar que los indígenas asumirían sería el de aliados militares de los portugueses, combatiendo contra aquellos "invasores" y contra los indígenas que se aliaban a estos. 


\section{Bahia, Espírito Santo y São Paulo. El objetivo fue fundar un poblado (Rio de Janeiro) y} combatir contra los tamoios, desalojándolos y ocupando sus territorios. Los franceses que vivían entre los indígenas - menos de una decena- fueron presos y ahorcados. El jefe principal Aimbirê fue asesinado durante los combates y sus seguidores fueron tomados como prisioneros; mientras tanto, otro grupo de indígenas bastante extenso emprendió la retirada por mar hacia la región de Cabo Frio, utilizando aproximadamente unas doscientas canoas.

$$
\text { La terce }
$$
levados como cautivos para las haciendas recién instaladas en Rio de Janeiro.
Apoyándonos en los datos demográficos ofrecidos por Pero de Magalhães Gândavo, podemos concluir que ese número de cautivos representaba más del quíntuplo de los residentes portugueses en aquel lugar.

41 El resto de las guerras emprendidas contra los indígenas por Mem de Sá -tercer gobernador general del Brasil- estuvieron umbilicalmente ligadas al avance de la colonización, sin que entre sus motivaciones existiera ninguna conexión con otros invasores europeos. Durante dos décadas, Mem de Sá promovió guerras (decretadas como “justas") contra los tupinambás del llamado recôncavo baiano ${ }^{21}$, contra los tupiniquins del sur de Bahia y Espírito Santo, y contra los caetés de Pernambuco. En las décadas

La tercera expedición, realizada casi diez años después y compuesta exclusivamente por moradores e indígenas, fue dirigida contra los tamoios que habían huido de la Bahia de sur de Bahia y Espirito Santo, y contra los caetés de Pernambuco. En las décadas 
siguientes la "guerra justa" fue dirigida contra los aymorés en Porto Seguro e Ilhéus, y contra los potiguaras de Paraíba y de Rio Grande do Norte.

La ferocidad de la acción represiva revelaba una clara intención de ejemplaridad; prueba de ello fue la campaña realizada por Mem de Sá contra los tupiniquins. En 1560, este gobernador fue informado de que "el gentío tupiniquim de la capitanía de Ilhéus se había rebelado, matando muchos cristianos, destruyendo y quemando todos los ingenios (...) Los moradores están sitiados". Hacia allí se dirigió, llevando indígenas de las misiones junto a los soldados portugueses, "llegando a una aldea que estaba a siete leguas (42 km) de la villa, situada en un pequeño alto, toda cercada por agua". Después de esta descripción casi bucólica, súbitamente pasa al relato de la acción militar: “(...) destruí [la aldea] y maté a todos los que querían resistirse, y a la vuelta vine quemando y destruyendo a todas las aldeas que quedaban atrás". Aparecieron más indígenas tupiniquins que fueron acorralados contra el mar, en donde lucharon y murieron a manos de otros indios. "No quedó vivo ningún tupiniquim; todos fueron traídos a tierra y dispuestos a lo largo de la playa, alcanzando sus cuerpos cerca de una legua" (Souza, 2000, pp. 50-51).

En el espacio de 30 días aquella tierra había sido pacificada; los indígenas que salían de los montes y matorrales venían "a pedir misericordia, e hice las paces con la condición de que serían vasallos de Su Alteza, pagando tributo y reconstruyendo los ingenios". Durante los años siguientes, los cronistas destacaron que los tupiniquins se transformaron en los más fieles aliados de los portugueses, componiendo la mayor parte de la tropa que derrotó a los tamoios de la Bahia de Guanabara.

\section{La fundación de la Colonia}

Por haber sido la sede del gobierno general, la capitanía de Bahia fue el lugar donde se expresaron más nítidamente las intenciones del proyecto colonizador. Los moradores de la antigua villa de Pereira recibieron no sólo un gobernador sino también todo un staff dirigente, el cual incluía un ouvidor (juez), un proveedor, misioneros, soldados, un maestro mayor de obras y artesanos. En poco tiempo, en donde hoy se encuentra la ciudad de Salvador da Bahia, 600 colonos y 400 desterrados (Souza, 2000, pp. 89-101) tuvieron que producir toda una infraestructura gubernamental (Casa de Gobierno, Audiencia, Cámara, Aduana, Hacienda, fuertes y cuarteles, prisiones, la capilla de Nossa Senhora da Conceição, depósitos, herrerías y casas para los colonos). La totalidad del conjunto fue erguida en un terreno previamente cercado, dotado con bastiones de artillería.

En pocos años, la población de Bahia aumentó casi seis veces. En la década de 1570, Gândavo calculó 1.200 casas y un poco más de 6.000 personas (Gândavo, 1995, pp. 67-123). Para 1585 ese número se había duplicado: los portugueses llegaban a 11.000, mientras la población total correspondía a 22.000 (Anchieta, 1988, pp. 418-431). Según otras fuentes, hacia 1590 la capitanía real habría estado comprendida por casi 30 mil moradores (Soares, 1996, p. 11; Couto, 1995, pp. 276-277).

Tomé de Souza, primer gobernador general del Brasil, concedió sesmarias de tierras a sus principales colaboradores, quienes en los años siguientes implantaron haciendas e ingenios en las inmediaciones. La cantidad de ingenios también se multiplicó, lo cual permite evaluar el vertiginoso crecimiento de la región: antes de ser fundada la ciudad 
había un único ingenio, pasando a haber 18 en 1570; 46 en 1585 y 50 en 1590 (Couto, 1995, p. 287).

Entre otros beneficios, en 1550 Tomé de Souza otorgó una sesmaria a los jesuitas, en donde fue erigido un colegio para huérfanos que abrigaba cerca de 60 niños y niñas (la mayoría indígenas) (Couto, 1995, p. 320).

No existe información sobre asentamientos de aldeas durante los primeros años de la presencia jesuita. Antes de 1557 son mencionadas solo dos, una de ellas (São Sebastião) vecina a la ciudad, y la otra localizada a unos $9 \mathrm{~km}$ (Nossa Senhora, en Rio Vermelho). En 1557 ya había cuatro aldeas, con una población total de 10.000 personas. Su número fue in crescendo llegando a 11 en 1562, con una población total de 34.000 indígenas (Marchant, 1980, p. 95).

Indiscutiblemente, ese crecimiento demográfico, económico y territorial tuvo como base el trabajo indígena. Las nuevas aldeas acompañaban la implantación de haciendas e ingenios, dispuestos a una distancia que iba desde $20 \mathrm{~km}$ hasta $180 \mathrm{~km}$ de la ciudad de Salvador da Bahia. Los indios que vivían en las aldeas jesuitas conformaban, por sí mismos, cinco veces más que el conjunto de moradores portugueses registrados por Gândavo en la década siguiente ${ }^{22}$.

\section{Las reacciones de los tupinambás y los caetés}

Sin embargo, el avance de la colonización no sucedió sin conflictos y resistencia por parte de los indígenas. La primera movilización tuvo lugar en 1554 y duró casi dos años. Fue vencida por una expedición punitiva, compuesta por 70 hombres y seis caballeros comandados por el hijo del segundo gobernador general del Brasil, Don Duarte da Costa. Encontraron solo algunas emboscadas por el camino; sin ninguna resistencia activa, capturaron al morubixaba (jefe) e incendiaron dos aldeas vecinas que, supuestamente, le habrían brindado su apoyo.

Poco tiempo después llegaron noticias de que se habían reunido seis aldeas tupinambás y habían sitiado un ingenio que pertenecía a uno de los más ilustres colonos de la región. En aquella oportunidad la expedición punitiva partió con aproximadamente 200 hombres, que vencieron cerca de 1.000 tupinambás y quemaron sus aldeas.

51 En una tercera fase, al año siguiente -y como consecuencia de la persistencia de los focos de conflicto- este mismo gobernador ordenó que fueran destruidas todas las aldeas en las que hubiera cercas (entendidas como preparativos bélicos contra los portugueses), con el propósito de que los tupinambás se sometieran, juraran lealtad al Rey y se comprometieran a pagar tributo ${ }^{23}$. Otro corolario de esa modalidad de acción colonial fue la instalación de los tupinambás en las aldeas creadas por los jesuitas, de las cuales saldrían para trabajar en los ingenios o para integrar las nuevas expediciones de guerra.

En 1558, las reacciones negativas a las normas más rígidas de la catequesis se unieron a la insatisfacción de los tupinambás ante la pérdida progresiva de sus territorios. Al comando de 300 portugueses y 4.000 indios provenientes de las aldeas, Mem de Sá dio inicio a la llamada "Guerra del Paraguaçu", destruyendo entre 130 y 160 aldeas tupinambás de la región del recôncavo. En aquella oportunidad, la sumisión de los indígenas incluía la plena aceptación de las nuevas normas de catequesis. 
53 En 1662, cerca de 30.000 personas fueron víctimas de una epidemia de viruela en Bahia, principalmente en las aldeas misioneras. También se encuentra registrada otra irrupción epidémica en 1584. Tanto las enfermedades como las fugas resultantes de la insatisfacción general con la nueva situación provocaron una enorme disminución del contingente de indígenas de la capitanía; según Gândavo, en 1576 habrían sobrevivido solo 8.000. Según el padre Anchieta, hacia 1585 la cantidad de esclavos africanos correspondía a un poco más de $1 / 3$ del número de indígenas.

54 Las investigaciones han revelado que el trabajo indígena fue la mano de obra fundamental en el Brasil del siglo XVI. Basándose en el estudio de la documentación existente sobre el ingenio real Sergipe, Stuart Schwartz demostró que en 1572 la mano de obra indígena representaba el 93\%, mientras que los esclavos africanos conformaban el 7\% restante. Entre los indígenas, el contingente más importante era el de los tupinambás, seguidos por los caetés y los tapuias; también existen registros de individuos procedentes de poblaciones distantes, tales como los tamoios y carijós (Schwartz, 1988, pp. 60-69).

En 1562, como "represalia" por la muerte de unos náufragos que había tenido lugar ¡seis años antes! (entre los cuales se encontraba el primer obispo del Brasil), el gobernador Mem de Sá declaró "guerra justa" contra los caetés que ocupaban el litoral, desde el norte de Bahia hasta Pernambuco ${ }^{24}$. Después de sometidos $-\mathrm{y}$ tal como había ocurrido con los tupinambás del recôncavo-, los caetés sufrieron otro flagelo: una epidemia de viruela mató aproximadamente a 70.000 de ellos (Marchant, 1980). Sometido militarmente y arrasado por la viruela, el gentío caeté de la capitanía de Pernambuco dejó de ofrecer resistencia armada a los colonizadores.

En 1546, los ingenios existentes en Pernambuco eran cinco; en 1570, veintitrés, y en 1585, sesenta y seis. Por su parte la población también iba en aumento, pasando de un poco más de 3.000 habitantes en 1546 a aproximadamente 8.000 en 1585 (Couto, 1995, pp. 276-277, 287). Unos años antes, Gândavo había observado que en esa capitanía "había muchos esclavos indios; ellos son la principal riqueza de la tierra. De aquí se los llevan y son comprados por otras capitanías, porque en esta hay muchos y son más baratos que en el resto de la Costa".

Lo que tales hechos revelan es que la guerra de conquista de la "Costa del Pau-Brasil", iniciada con el establecimiento de un gobierno general, tuvo como finalidad someter a la población autóctona, ocupando sus territorios y movilizando su fuerza de trabajo.

\section{El cambio de mediadores: los “lanzados” y los misioneros}

Lo paradójico de todo esto es que el éxito inicial de la colonización dependería de la red de relaciones constituida durante el régimen de las factorías. Una figura esencial en aquel contexto fue la del intermediario, del lado portugués los "lanzados", del lado francés los truchements. Al aprender los idiomas y las costumbres nativas, estos traductores culturales no eran simplemente "lenguaraces" (intérpretes); más bien, fueron los operadores prácticos de las alianzas. Contraían matrimonio con mujeres indígenas heredando redes de relaciones políticas y ceremoniales, lo cual les permitía actuar como agentes de producción del pau-brasil y como mediadores en las relaciones con los europeos. Las familias instituidas por ellos constituyeron las raíces de los más antiguos moradores de la colonia, como sucedió en São Paulo, Bahia y Pernambuco (véase Madre 
de Deus, 1975, entre otros). Los propios ideólogos de la colonización, situados en la metrópolis, valorizaron en aquel momento al mestizaje como estrategia política y de poblamiento ${ }^{25}$.

La cooperación de los indígenas era esencial. Esto era reconocido explícitamente: en diciembre de 1548, el Rey había enviado una carta a Diogo Álvares -también llamado Caramuru-, solicitando que intermediara en la relación con los indígenas y que apoyara la implantación de un núcleo dirigente. Antes de regresar a Portugal, el primer gobernador Tomé de Souza otorgó la investidura de caballeros a tres hijos y un yerno de Diogo Álvares debido a los relevantes servicios prestados a la Corona como intermediarios con los indios (Couto, 1995, pp. 239-242). Sin el acuerdo y la mano de obra de las poblaciones autóctonas no habría sido posible establecer la infraestructura indispensable para el desarrollo del proyecto colonial, incluyendo en ella desde las construcciones públicas hasta el pleno funcionamiento de los ingenios.

Otro ejemplo similar es el de la capitanía de Pernambuco, la más próspera de todas. Los portugueses pudieron expandirse en dicha región gracias a una alianza con los tabajaras. El primer asentamiento (Igarassu) estaba localizado en un terreno cedido por ellos. Jerônimo de Albuquerque, cuñado del donante, contrajo matrimonio con una hija del cacique Arcoverde y tuvieron una extensa prole, dando origen a algunas de las más viejas familias locales. Con la fundación de Olinda (1535) en las tierras de los caetés, se instauró un conflicto que se extendería por más de dos décadas. En algunas ocasiones los caetés consiguieron imponerse a los tabajaras, sitiando Igarassu y Olinda (Staden, 1974 [1557], pp. 47-51).

61 En el proyecto de colonización de la segunda mitad del siglo XVI, los intermediarios en el tratamiento con el gentío no serán los "lanzados", sino los misioneros. A esa altura estos ya no convivían pacíficamente con las costumbres indígenas, imponiéndoles por ello valores e instituciones portuguesas. Estas destacadas figuras del proyecto colonial fueron las que fundaron las aldeas reuniendo a los autóctonos en espacios limitados, encargándose de su civilización y catequesis.

La Regiduría de Tomé de Souza - pieza clave para la institución del primer gobierno central en el Brasil- se basaba claramente en la tradición jurídica ibérica, clasificando a los enemigos en dos tipos: los que aceptaban la conversión y se sometían a los soberanos católicos, transformándose en sus súbditos, y los que mantenían su condición de "infieles" y debían ser combatidos, ejecutados o esclavizados. 
Hombre tupinambá, de Albert Eckhout, 1643

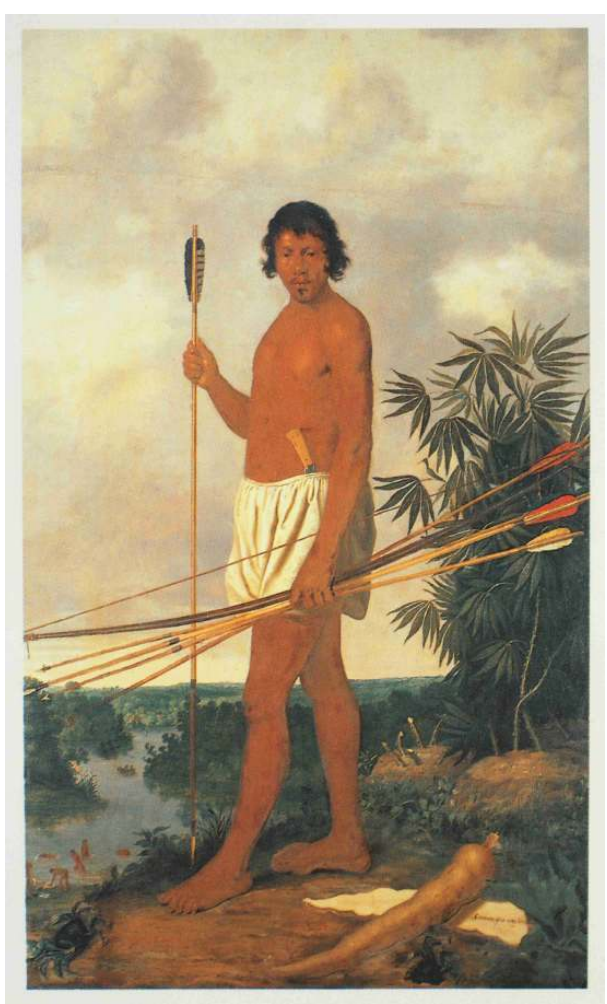

Hombre tapuia, de Albert Eckhout, 1641

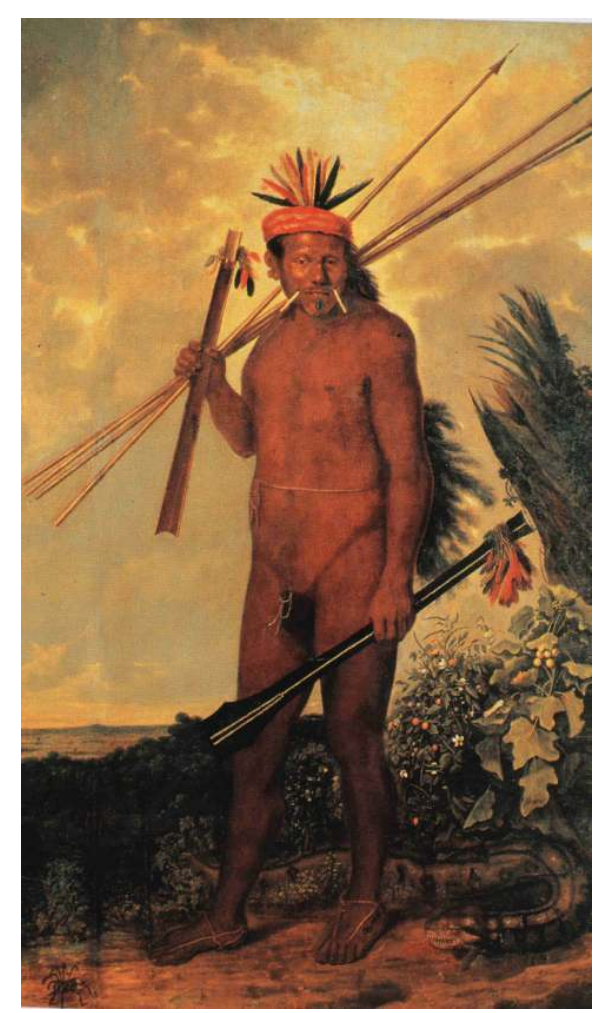

63 La doctrina de la "guerra justa" no solo exigía el castigo a los infieles, sino también la reorientación de aquellos que se habrían sometido. La actuación de los colonizadores no 
debía restringirse a la dimensión política o económica; para justificarla, era necesario destacar su aspecto ético y espiritual (Nóbrega, 1954). Al llegar a Bahia, el padre Nóbrega quedó impresionado con la generalidad de una costumbre entre los moradores: la posesión de nativos como esclavos. Tales hechos desafiaban la bula papal "Veritas Ipsa" promulgada por Paulo III en 1537, en la cual se afirmaba que las poblaciones autóctonas de América poseían alma y que no debían ser objeto de malos tratos o de esclavitud. Para que la conquista se adaptara a los parámetros de una "guerra justa", era necesario darle un fundamento religioso; se trataba entonces de producir una verdadera conversión del gentío, ejerciendo sobre él "el suave yugo de Cristo". La continuidad de la poligamia, de la antropofagia y de la intervención de los pajés (chamanes) serían condiciones inaceptables para la catequesis.

En realidad, misioneros, moradores y administradores estaban insertos dentro de un denso tejido de relaciones de interdependencia. En varias ocasiones, durante sus visitas a las capitanías el padre Nóbrega viajó junto con los gobernadores, acompañando sus campañas militares y participando de las negociaciones con los indígenas. La mayoría de los religiosos no se ocupaba de los nativos, sino principalmente de la asistencia espiritual a los colonos. Los más influyentes catequistas del siglo XVI, los padres Nóbrega y Anchieta, expresaron en diversas cartas la creencia de que la "guerra justa" contribuía efectivamente para la conversión del gentío.

La demanda por el trabajo indígena en las haciendas e ingenios debía ser atendida principalmente a través de los indios de las misiones mediante el pago de salarios, con condiciones que no desestructuraran la economía de las aldeas ni inviabilizaran la catequesis (véase Perdigão Malheiro, 1976). La cantidad de instrucciones reales ordenando pagar los servicios prestados por los indígenas sugiere que las normas establecidas para cumplir tales condiciones habrían sido continuamente burladas. Cabe notar también que solo una parte muy pequeña de esos sueldos era efectivamente destinada a los indígenas, lo cual demuestra la distancia entre esa forma de reclutamiento y el trabajo libre.

66 La respuesta indígena al deterioro de sus propias condiciones de vida en las aldeas fue fugarse de ellas, generando perjuicios que aumentaban la ineficiencia e inviabilidad del sistema. Una alternativa para los misioneros fue entonces orientarse hacia las regiones del sertão, intentando establecer aldeas en lugares más alejados de las presiones de la economía colonial, ya instalada en la costa litoral.

67 Generalmente, los misioneros son presentados como protectores de los indígenas; de sus escritos han salido la mayoría de los relatos que poseemos sobre aquellas culturas. Sin embargo, es fundamental entender que la perspectiva que guió sus miradas fue la de la catequesis; esta interpretaba al indígena como un ser bruto e imperfecto, cuyo único valor residía en su potencial cristiano. Las técnicas poco convencionales de la catequesis (tales como el teatro y la música), la incorporación de algunos símbolos nativos (resignificados), el conocimiento de las lenguas nativas y la enseñanza de una "lengua general" no excluyeron ni los descimentos ${ }^{26}$, ni una pedagogía de los castigos, ni la utilización de la fuerza (cuando fue considerada imprescindible) (Baeta Neves, 1978). La necesidad de convertir al gentío justificará la defensa de su libertad (contraponiéndose a los malos tratos y a los abusos de los moradores), pero también legitimará las acciones bélicas como parte de una guerra santa.

La satanización de las religiones, el horror a la antropofagia y al espíritu guerrero de los indígenas aparecen fuertemente representados tanto en las ilustraciones de las crónicas 
publicadas por los misioneros como en los registros de los viajeros de mediados del siglo XVI. Las imágenes que recorrerían el mundo presentaban a los indígenas del Brasil como caníbales feroces, congelando en el tiempo las expectativas y las discusiones filosóficas que suscitaban ${ }^{27}$.

La expansión de haciendas e ingenios a lo largo de los territorios habitados por indígenas era viabilizada a través de los descimentos y la creación de aldeas, reubicándolos en espacios más limitados y bajo la supervisión de los misioneros. De esas aldeas saldrá la reserva de trabajadores que permitió el nacimiento económico de la colonia; también de allí provendrá una parte sustancial de las tropas que combatirán contra los indígenas refractarios al dominio portugués y contra los invasores franceses.

En tal contexto, la colonización ya no se basaría en el mestizaje y en la convivencia de instituciones portuguesas e indígenas, sino en el matrimonio católico y monogámico, el bautismo y la conversión. Hubo una reiterada preocupación de los misioneros por la llegada de mujeres portuguesas que pudieran casarse y engendrar familias verdaderamente cristianas, las cuales debían constituir el apoyo moral de la colonia.

71 Fueron pocos los indígenas que consiguieron algún tipo de proyección social, restringiéndose esta a las familias que colaboraron en las conquistas militares y resultaron agraciadas con sesmarias y/o distinciones especiales (el ejemplo más evidente de ello quizá sea el de Araribóia). En otros momentos de la historia del Brasil en los que el territorio y la soberanía estuvieron en disputa, algunas personalidades indígenas contaron con ciertos mecanismos de prestigio y de relativa movilidad social. Otro caso notable tuvo lugar durante la ocupación holandesa (1630-1654), particularmente en la figura de Antonio Felipe Camarão.

72 La guerra de conquista, con los descimentos, las aldeas misioneras y las "guerras justas", transformada en mecanismo de expansión de la frontera económica, fue transplantada hacia los sertões en el siglo XVII y la primera mitad del siglo XVIII, trazando capítulos futuros de la historia de la formación territorial brasileña. Los llamados bandeirantes paulistas $^{28}$, con sus tropas de indios esclavizados y mamelucos (mestizos de portugueses e indios), también fueron contratados para actuar en áreas distantes, disputándose con los misioneros la intermediación y el control del gentío. En algunas partes, las tropas de ganado serán el vector básico para el avance de la frontera.

\section{Los indígenas como mano de obra secundaria}

73 La tercera situación es la de la plantation esclavista de fines del siglo XVI, orientada hacia la exportación del azúcar y basada en la mano de obra africana. Esta se mantendrá hegemónica durante los próximos dos siglos. Era el modelo de colonización practicado en algunas partes de la América Española, especialmente en las islas del Caribe, en donde la población autóctona fue exterminada en pocas décadas y toda la fuerza de trabajo utilizada en el monocultivo provino de los esclavos africanos ${ }^{29}$.

No obstante, fue la guerra de conquista de la "Costa del Pau-Brasil" la que viabilizó y acabó por establecer dicha modalidad económica, consolidándose en el siglo siguiente durante la dominación holandesa. Instalado en las aldeas del litoral, el contingente de indios liberados disminuyó bastante, en virtud de las dificultades de convivencia entre las aldeas y la creciente demanda de fuerza de trabajo por parte de los ingenios. Según John 
Hemming (1978), hacia mediados del siglo XVII los indios liberados serán aproximadamente un tercio de los que había en 1590 en el litoral ${ }^{30}$.

Ingenios y plantaciones de caña de azúcar (con esclavos negros) y plantaciones de mandioca (con indígenas) - Plantaciones en Pernambuco - Schwartz, 1988.

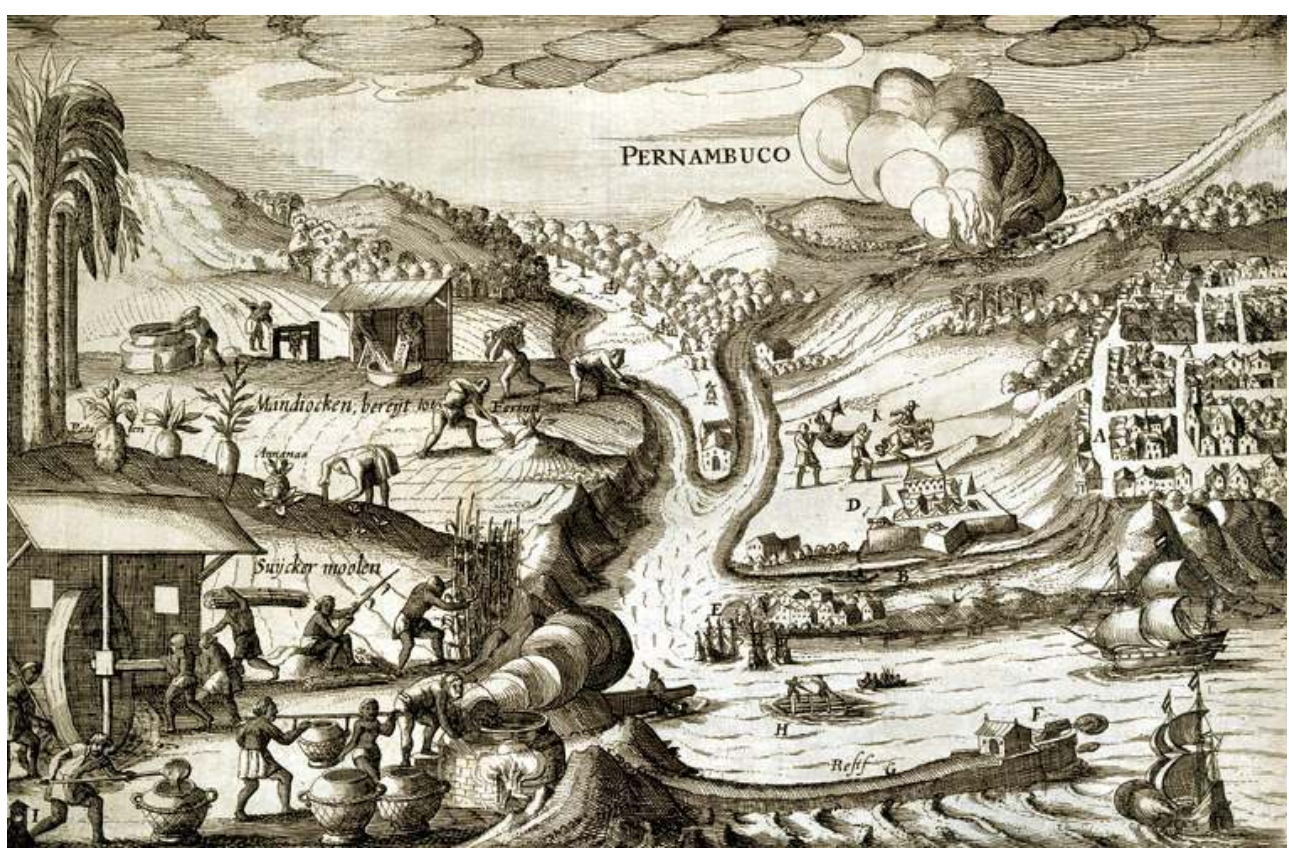

75 Con la implantación progresiva de ese modelo económico, la población autóctona comenzará a ser gradualmente dirigida hacia otras actividades menos lucrativas, aunque todavía imprescindibles a la vida de la colonia (modos de producción subsidiarios, actividades de subsistencia y prestación de una gama heterogénea de servicios a los colonos). No contamos con datos cuantitativos, pero el relato de los cronistas inmediatamente posterior a la guerra de conquista del litoral- resulta bastante elocuente:

Las personas que quieren vivir en el Brasil y que por ello se vuelven moradores de la tierra, por más pobres que sean, si cada uno de ellos llega a tener dos pares o media docena de esclavos (que uno por otro puede costar un poco más o menos de diez cruzados), enseguida encuentra remedio para su sustento; porque unos pescan y cazan para él, otros le mantienen la hacienda, y así poco a poco enriquecen los hombres y viven más honradamente en la tierra, con más descanso que en este reino [Portugal] (...) Los propios esclavos, indios de la tierra, buscan qué comer para sí y para sus señores; de esta manera no crean gastos para los hombres, ni con su mantenimiento, ni con sus personas. (Gândavo, 1995, pp. 16-17).

76 La imagen ofrecida por Gândavo es incorporada y repetida por fuentes posteriores. En los Diálogos das Grandezas do Brasil, el portugués Brandônio, un personaje creado por el autor Ambrósio Fernandes Brandão (propietario de tierras en Pernambuco hacia fines del siglo $\mathrm{XVI}$ ), afirma que "la mayor parte de la riqueza de los labradores de esta tierra consiste en tener pocos o muchos esclavos", mencionando a continuación que su sustento era asegurado a través de esclavos que regularmente salían a pescar y cazar para su señor ( Brandão, 1997 [1618], p. 213). De la lectura y compilación de documentos de la época, Pereira da Costa (1983) también llega a una síntesis similar: "No había blanco, por más pobre que fuese, que no tuviera veinte o treinta indios que lo sirvieran como cautivos; los ricos tenían aldeas enteras". 
77 En aquel momento, la fuerza de trabajo no especializada y altamente discriminada contando siempre con un bajísimo valor económico y funcionando como un antídoto contra la pobreza de los ciudadanos comunes- está iniciando su larga trayectoria en la historia del Brasil. La práctica cotidiana del cautiverio demostrará a los individuos de origen autóctono que en tal contexto no habrá ninguna alternativa posible de supervivencia a través del mantenimiento de su cultura y/o de la afirmación de su identidad. Fueron condenados a ingresar en una zona de invisibilidad, sumergiéndolos en una especie de anonimato del cual solo podrán escapar hacia fines del siglo XX, en un contexto histórico absolutamente distinto.

A pesar de haber sufrido una enorme reducción poblacional, los indígenas de la costa atlántica no fueron extinguidos a lo largo del siglo XVI, como suponen ciertas expectativas y prejuicios aún vigentes. Las investigaciones realizadas por antropólogos durante esta última década han demostrado la existencia de más de tres decenas de colectividades que, en los sertões y la costa atlántica del nordeste brasileño, se autoidentifican como indígenas (entre ellas, poblaciones litoraleñas que fueron objeto de extensas crónicas y acciones coloniales, tales como los potiguaras, tupinambás y tupiniquins ${ }^{31}$ ). El hecho de no poseer un reconocimiento oficial explícito no significa de ningún modo que esas personas hayan dejado de establecer redes de intercambio y de solidaridad, y/o de configurar formas de organización específicas reuniendo familias y grupos en el interior de un conjunto social más amplio (Pacheco de Oliveira, 2004, pp. 13-42).

\section{Consideraciones finales}

En lo que concierne a los indígenas, la historia oficial del Brasil conduce inevitablemente a una línea narrativa e interpretativa caracterizada por tres equívocos. Es absolutamente inviable pretender comprender la presencia de los indígenas en la historia nacional y en la contemporaneidad sin ejercer una crítica radical sobre dichos equívocos, ya sea para señalar su ineficacia como instrumentos descriptivos y analíticos, como también para explicitar los presupuestos políticos e ideológicos en los que se apoyan.

El primero de ellos es que todos los discursos relacionados con los indígenas pasan necesariamente por la polaridad "protección/exterminio". No importa a qué período histórico, región o etnía esté refiriéndose el narrador; todos los personajes, leyes y eventos que surgen en su relato siempre resultan agrupados en función de una condición de protectores o predadores de indios.

Esa dualidad se remonta a los primeros escritos de los misioneros en el Brasil, volviéndose mucho más rígida e imperativa en el siglo XVII (sobre todo en los escritos del padre Antonio Vieira). Será el eje de todas las narrativas históricas posteriores sobre el indígena, llegando hasta el siglo XX y extendiéndose hasta nuestros días. No se expresará solamente a través de la oposición jesuitas/colonos sino también en otros pares, tales como misioneros/directores (durante el período del Directorio Pombalino de 1755, imponiéndose por varias décadas hasta su extinción formal en 1798), o en la polaridad registrada durante el período republicano entre militares/extractivistas. Esta última marcó toda la historia del indigenismo oficial durante el siglo XX, entre militares (como agentes estatales y ejecutores de las leyes) y poderes locales (dedicados a formas atrasadas de producción capitalista). La polaridad exterminio/protección también está 
presente en las manifestaciones políticas actuales, pretendiendo clasificar a los agentes históricos en "indigenistas" y "anti-indígenas": los primeros serían los funcionarios de la FUNAI, FUNASA, MEC, MMA y el personal de las $\mathrm{ONG}^{32}$, mientras el segundo grupo estaría conformado por los funcionarios de otros órganos públicos, empresarios, propietarios rurales, usurpadores de tierras, etc.

Clasificar de esa forma maniqueísta y simplificada las acciones y los episodios en los que están involucrados los indígenas no nos lleva a una comprensión efectiva ni del espacio político que ellos ocupan actualmente y han ocupado en el pasado, ni de las múltiples formas de resistencia que desarrollaron en el tiempo, inviabilizando también cualquier expectativa (actual o futura) en relación con su protagonismo. Bajo este procedimiento, dicho discurso se revela como una pieza fundamental para legitimar la tutela, naturalizándola.

Es importante tener presente que, incluso representando una perspectiva opuesta a la de los colonos, los relatos de los misioneros no se empeñaron en criticar o reformular las apreciaciones negativas sobre los indígenas. Las crónicas de los misioneros del siglo XVI destacan principalmente los factores y las costumbres que diferenciaban radicalmente a portugueses y autóctonos. Ratificaban la necesidad de la conversión y tutela de los indígenas, valorizando las dificultades del emprendimiento religioso al que se dedicaban.

A diferencia de lo que podría parecer la visión polarizada que venimos criticando (la cual pretende oponer un humanismo cosmopolita a un tosco egoísmo local), durante el siglo XVI la actividad misionera y las acciones punitivas caminaron juntas, integrándose mutuamente como constitutivas de la conquista de las poblaciones autóctonas y de la implantación del orden colonial.

Las referencias a los misioneros y a los colonos apuntan hacia un mismo problema -la disputa sobre el control del trabajo indígena- y proceden de acuerdo con las misma base jurídica e ideológica, en donde la "civilización" del indio (entiéndase aquí su sumisión política, su utilización como trabajador y la salvación de su alma a través de la catequesis) era vista como un valor y una necesidad.

La convergencia de intereses entre misioneros y colonos condujo a una aparente unidad de las fuentes en cuanto a la caracterización de los indígenas, que pasaron a ser vistos como "naturalmente" refractarios al trabajo, virtualmente peligrosos, necesitados de tutela y civilización. Ello permite sospechar de la inexactitud de las investigaciones históricas que tienden a otorgar a los indígenas un papel secundario o inexistente en la formación nacional.

También se equivocan las perspectivas dualistas que los colocan eternamente frente al dilema de someterse o resistir, de aceptar la aculturación o ser exterminados. Y aquí entra el segundo equívoco: la Pax, objetivo de la acción colonial, es un estado jurídicoadministrativo (es decir, militar, diplomático), no una descripción sociológica. Implica únicamente el establecimiento de una circunscripción territorial (administrativa) en términos muy generales de convivencia, demandando principalmente el cese de los enfrentamientos armados. El orden que dicha Pax introducía refleja el punto de vista de los colonizadores, pero nada nos dice respecto a la recepción y utilización de tales normas por los nativos, ni tampoco nos informa sobre las prácticas efectivamente vigentes en la colonia (incluso aunque contradigan lo dispuesto en los reglamentos).

Frente a las reglas estipuladas, ¿cuál fue el grado de refracción del comportamiento de los nativos tolerado por los colonizadores? En general, las evaluaciones de los misioneros se 
revelan bastante más exigentes que las de los funcionarios reales o los colonos, cuya insatisfacción era dictada por intereses concretos en la tierra o en el trabajo indígena. Sin embargo, accionar los mecanismos represivos poseía un gravamen -en términos de recursos, tiempo y energía- que los administradores habrían estado dispuestos a pagar solo en situaciones extremas. La tendencia fue que los límites de lo intolerable se situaran en la existencia de conflictos armados que colocasen en riesgo la seguridad física y patrimonial de los colonizadores (con la invasión o destrucción de ingenios y haciendas, o con ataques a/muertes de portugueses).

Aunque la llamada pacificación aparenta haber sido algo definitivo e irreversible -una iniciativa que resolvía la contradicción entre civilización y barbarie, entre orden y caos-, fue un procedimiento repetido con frecuencia, una necesidad recurrente. Los tupinambás, por ejemplo, fueron colocados en aldeas misioneras y configuraron la fuerza de trabajo esencial para la economía colonial durante el siglo XVI (Maestri, 1995), pero no dejaron de movilizarse en acciones militares, en articulaciones políticas entre jefes y en movimientos religiosos (que incomodaron bastante a las autoridades portuguesas ${ }^{33}$ ). Aunque en todas las oportunidades (tanto en 1556 como en 1558 y 1562) los gobernadores anunciaron al Rey la total sumisión de los tupinambás; los documentos posteriores siguieron refiriéndose a los conflictos con ellos en la misma región a fines del siglo XVI y en el siglo XVII. También allí, inclusive, tuvo lugar el surgimiento de fenómenos religiosos (como el caso de la "santidad del Jaguaripe", en 1585), que fueron reprimidos en función de haber producido una masiva fuga de esclavos de las haciendas vecinas y en virtud de la acusación de que perjudicaría la producción agrícola del resto de los propietarios.

Recién a partir del momento en que los hechos fueron considerados graves por obstaculizar el avance de la colonización, se implementaron registros para hablar de ellos, haciéndolos memorables. Pero bajo la ausencia de tales condiciones, cualquier otra forma de resistencia cultural ha sido en general condenada al silencio y a la invisibilidad. El ejercicio del Derecho y de la Palabra era un privilegio de los europeos; como observa Michel de Certeau (1982), ello afectó tanto a la escritura de la historia como a la propia producción de las fuentes historiográficas, dificultando la reconstrucción del cotidiano de las relaciones entre indígenas y colonizadores para escapar del esquematismo de la historia oficial.

El tercer equívoco de esa narrativa es la instauración de un clivaje radical y definitivo entre indios y no indios, organizados bajo un padrón disyuntivo que no admite mezclas, sobreposiciones o alternancias, inspirado en el modelo religioso del pagano/cristiano.

A diferencia del negro, no es posible pensar en el eventual surgimiento de una categoría intermediaria ("mestizos") dado que indios y blancos fueron conceptualizados como tipos absolutamente distintos y polarizados en términos de actitudes y valores. O la persona optaba por mantenerse como "indio" (que significaba rehusar el dominio portugués y hacerse cargo de las obligaciones reservadas a los enemigos), o asumía completamente su condición de "vasallo". La clasificación realizada por otros habría dependido no solo de la autoidentificación (producida de forma individual o en el ámbito familiar), sino principalmente a partir de las representaciones que los colonizadores construyeron sobre las conductas de una persona determinada y de los intereses concretos puestos en juego en su relación con ella.

93 Como consecuencia de tales parámetros ideológicos, las poblaciones autóctonas serán reiteradamente representadas a partir de la imagen del "indio bravo"34, debido a que tales apreciaciones siempre estuvieron relacionadas a la condición tutelar que ocuparon (y 
ocupan) en diferentes proyectos nacionales. Aquellos que aceptaron el bautismo y la condición de vasallos ya no debían ser descritos de forma diferente al resto de los otros súbditos del Rey, ni tampoco debían ser asociados por ningún motivo a los que todavía mostraban diferencias importantes y se asemejaban a los "indios bravos". Ello explica la virtual inexistencia de registros sobre familias y colectividades indígenas que optaron por vivir dentro de la sociedad colonial, ignorándose la especificidad de sus formas socioculturales, así como el establecimiento de sus líneas de continuidad con tradiciones culturales autóctonas.

Hay una tendencia a pensar el mestizaje en el Brasil exclusivamente como una confluencia de descendientes de portugueses y africanos, omitiendo totalmente los entrecruzamientos con la población nativa y las estrategias sociales antagónicas contenidas en dichos entrecruzamientos. La importancia del indígena en la formación de la familia brasileña es algo muy poco investigado, que solo aparece en algunos ensayos con intención polémica ${ }^{35}$.

La incorporación de indígenas dentro de familias de descendientes de portugueses era algo estrictamente individual (sobre lo cual las convenciones recomendaban no hablar), que no afectaba las categorizaciones grupales y colectivas. La hipótesis sostenida por Gilberto Freyre (1933) ${ }^{36}$ para la atenuación de los estereotipos raciales y la valorización del mestizaje estaba asociada al relativo cambio de estatus de los negros dentro de la casagrande $^{37}$, implicando - para los negros que allí servían- procesos de mayor interacción y contigüidad con los blancos, inclusive con un relativo blanqueamiento de sus descendientes.

96 Al contrario, en el caso de los indígenas su incorporación dentro de familias portuguesas no se traduciría en el reconocimiento del mestizaje ni en una supuesta disminución de clivajes étnico-raciales, sino en la acentuación de los estigmas como indígenas. Esto también sucedería incluso por parte de los propios indígenas, quienes consideraban haber abandonado tal condición por medio del casamiento; esa actitud tendría una continuidad a través de la socialización de sus descendientes y del ocultamiento de memorias y prácticas pretéritas.

97 El mestizaje en el Brasil ha sido pensado apenas como algo racial, imaginando al indio como "soluble" en la colonización. Su destino sería el de una convivencia casi perfecta: la invisibilidad dentro de la sociedad brasileña. Como sabemos, la condición de indígena no tiene nada que ver con la raza o el color ${ }^{38}$. Para insertar adecuadamente su manifestación identitaria en el amplio espectro de la diversidad brasileña, es necesario operar con otros criterios (políticos, socioculturales y religiosos).

No obstante, permanece como una acusación la virtualidad de un estigma que será siempre comportamental y que podrá ser inequívocamente resuelto con la indicación de un tutor. El camino del mestizaje no es únicamente el de la movilidad (jesto es un eufemismo!), sino también el de la permanente construcción de tutores y tutelados, lugares políticos en continua refabricación a través de estigmas y segregaciones.

Entender la diversidad étnica en el Brasil exige incorporar muchas historias perdidas de familias, afectos, memorias y diásporas que atraviesan las fronteras étnicas y muestran, críticamente, los límites de la etnificación. Es necesario repensar la historia del Brasil en su complejidad y singularidad, sin apelar a las categorías derivadas de modelos jurídicos coloniales o de una estructura narrativa tributaria de un modelo de nación en el cual no hay espacio para la reducción de las desigualdades o el ejercicio de la ciudadanía. 


\section{BIBLIOGRAFÍA}

Anchieta, J. (1998). Cartas, Informações, Fragmentos Históricos e Sermões (1554-1594). Belo Horizonte/ São Paulo: Itatiaia/Edusp.

Baeta Neves, L. (1978). o Combate dos Soldados de Cristo na Terra dos Papagaios: Colonialismo e repressão cultural. Rio de Janeiro: Forense.

Belluzzo, A. (Org.). (2000). o Brasil dos Viajantes. São Paulo: Objetiva. Metalivros, 2000.

Benjamin, W. (1986). Sobre o conceito de história. En Obras Escolhidas. Magia e técnica, arte e política. São Paulo: Editora Brasiliense, $2^{\text {a }}$ Edición.

Brandão, A. (1997 [1618]). Diálogo das Grandezas do Brasil. Organización e Introducción de José Antonio Gonçalves de Mello. Fundação Joaquim Nabuco/Editora Massangana, $3^{\text {a }}$ Ed.

Buarque de Holanda, S. (1959). Visões do Paraíso: Os motivos edênicos no descobrimento e colonização do Brasil. São Paulo: Brasiliense.

Carneiro da Cunha, M. (Org.). (1992). História dos Índios no Brasil. São Paulo: Companhia das Letras.

Castro, S. (Org.). (1985). A Carta de Pero Vaz de Caminha. Descobrimento do Brasil. S. Castro (Introducción, actualización y notas). Porto Alegre: L\&Príncipe Maximiliano.

Cezar, T. (2002). L écriture de l histoire au Brésil au XIXe siècle. Essai sur une rhétorique de la nationalité. Le cas Varnhagen. Thése de Doctorat, École dês Hautes Études em Sciences Sociales, Paris.

Cezar, T. (1999). Varnhagen e os relatos de viagem do século XVI: Ensaio de recepção historiográfica". Anos 90, 11, 38-53, São Paulo.

Cortesão, J. (1969). A Colonização do Brasil. Lisboa: Portugália Editora.

Couto, J. (1995). A Construção do Brasil. Lisboa: Edições Cosmos.

De Certeau, M. (1982). A escrita da história. Trad. de Maria de Lourdes Menezes. Rio de Janeiro: Forense.

Dennis, F. (1944). Uma festa brasileira. Rio de Janeiro.

Domingues, H. (1989). A noção de Civilização na visão dos construtores do Império. (A revista do Instituto Histórico e Geográfico Brasileiro: 1838-1850/60). Tesis de Maestría. Programa de Pós-Graduação em História, Universidade Federal Fluminense.

Fabian, J. (2001). Anthropology with an Attitud: Critical essays. Stanford: Stanford University Press.

Freyre, G. (1933). Casa-grande \& senzala. Introdução à história da sociedade patriarcal no Brasil (I). Rio de Janeiro: José Olympio Editora.

Gambini, R. (1999). Outros 500: uma conversa sobre a alma brasileira. São Paulo: Editora SENAC.

Gândavo, P. (1995). Tratado da Província do Brasil \& História do Brasil. Recife: Fundação Joaquim Nabuco/ Editora Massangana.

Greenblatt, S. (1996). Possessões maravilhosas: o deslumbramento do Novo Mundo. São Paulo: EDUSP.

Guimarães, M. (1989). Nação e civilização nos trópicos: o Instituto Histórico e Geográfico Brasileiro e o projeto de uma história nacional. Estudos Históricos, 1 (1), 5-27, Rio de Janeiro. 
Guimarães, L. (1995). Debaixo da imediata proteção de Sua Majestade Imperial. O Instituto Histórico e Geográfico Brasileiro (1838-1889). Revista do IHG, 388, Rio de Janeiro.

Hemming, J. (1978). Red Gold: The conquest of the Brazilian Indians. London: Macmillan.

Hespanha, A. (2001). A constituição do Império Português. Revisão de alguns enviesamentos correntes. En João Fragoso, M. F. Bicalho y M.F. Gouvêa (Orgs.), O Antigo regime nos Trópicos: A dinâmica imperial portuguesa (séculos XVI-XVIII), (pp. 163-188). Rio de Janeiro: Civilização Brasileira.

Knauss, P. (1991). O Rio de Janeiro da pacificação: franceses e portugueses na disputa colonial. Rio de Janeiro: Prefeitura da Cidade do Rio de Janeiro.

Kodama, K. (2005). Os filhos das brenhas e o Império no Brasil: a etnografia do IHGB (1840-1860). Programa de Pós-Graduação em História Social. PUC-RJ, Rio de Janeiro.

Lestringant, F. (1997). O canibal: grandeza e decadência. Trad. de Mary Lucy Murray Del Priore. Brasília: Editora UNB.

Madre de Deus, G. (1975 [1797]). Memórias para a História da Capitania de São Vicente. Belo Horizonte/São Paulo.

Maestri, M. (1995). Os senhores do litoral: conquista portuguesa e agonia Tupinambá no litoral brasileiro (século 16). Porto Alegre: Editora da Universidade/UFRGS.

Marchant, A. (1980). Do Escambo à Escravidão: As relações econômicas de portugueses e índios na colonização do Brasil (1500-1580). São Paulo/Brasília: Companhia Editora Nacional/INL.

Mello de Souza, L. (1993). Inferno atlântico: demonologia e colonização, séculos XVI-XVIII. São Paulo: Companhia das Letras.

Melo Franco, A. (1976). O Índio Brasileiro e a Revolução Francesa: As origens brasileiras da teoria da bondade natural. Rio de Janeiro: José Olympio.

Mendes Jr, J. (1912). Os indígenas do Brazil, seus direitos individuaes e políticos. São Paulo: Typ. Hennies Irmãos.

Miller, J. (1997). O Atlântico Escravista. Açúcar, escravos e engenhos. Afro-Ásia, 19/20, 09-36, Salvador: UFBA.

Monteiro, J. (1994). Negros da Terra: Índios e Bandeirantes nas Origens de São Paulo. São Paulo: Companhia das Letras.

Nassau, M. (Príncipe de Orange). (1906). Relatório de Maurício de Nassau aos Estados Gerais, ao retornar à Holanda. Revista do Instituto Archeologico e Geographico Pernambucano, XII (68). Junho de 1906.

Nóbrega, M. (1954). Diálogo sobre a conversão do gentio. Lisboa: Serafim Leite.

Pacheco de Oliveira, J. (1978). o Nosso Governo: Os Ticuna e o Regime Tutelar. São Paulo/Brasília: Marco Zero/CNPq.

Pacheco de Oliveira, J. (1999). Ensaios em Antropologia Histórica. Rio de Janeiro: Editora da UFRJ.

Pacheco de Oliveira, J. (2000). Entering and leaving 'the melting pot': Indigenous peoples in the Brazilian's national censuses. Journal of Latin American Anthropology. Society for Latin American Anthropology, AAA.

Pacheco de Oliveira, J. (2004). Uma etnologia dos 'índios misturados’? Situação colonial, territorialização e fluxos culturais. En João Pacheco de Oliveira (Org.), A Viagem da Volta: Etnicidade, política e reelaboração cultural no Nordeste Indígena, (pp. 13-42). Rio de Janeiro, Contra Capa, $2^{\text {a }}$ Ed. 
Pacheco de Oliveira, J. (Org.). (2011). A presença indígena no nordeste: processos de territorialização, formas de reconhecimento e regimes de memória. Rio de Janeiro: Contra Capa.

Pacheco de Oliveira, J. (2012). Mensurando alteridades, medindo direitos: Práticas e saberes governamentais na criação de fronteiras étnicas. Dados, Revista de Ciências Sociais, 55(4): 1055-1088.

Pacheco de Oliveira, J. (en prensa). Os indígenas na fundação da colônia: uma abordagem crítica. En João Fragoso e Fátima Gouveia (Orgs.), O Brasil Colonial. Rio de Janeiro: Editora Civilização Brasileira.

Pacheco de Oliveira, J. y Rocha Freyre, C. (2008). A Presença dos Índios na Formação do Brasil. Brasília: MEC.

Pagden, A. (1982). The Fall of Natural Man: the American Indian and the Origins of Comparative Ethnology. Cambridge: Cambridge University Press.

Perdigão Malheiro, A. (1976). A escravidão no Brasil. Rio de Janeiro: Vozes.

Pereira da Costa, F. (1983). Anais Pernambucanos, VI. Recife: Fundarpe

Prezia, B; Hoornaert, E. (1989). Esta terra tinha dono. São Paulo: FTD.

Raminelli, R. (1996). Imagens da colonização: a representação do índio de Caminha a Vieira. Rio de Janeiro: Jorge Zahar.

Ramos, A. y Albert, B. (Orgs.). (2002). Pacificando o branco: cosmologias do contato no norte amazônico. São Paulo: UNESP/Imprensa Oficial do Estado.

Ribeiro, D. (1970). Os índios e a civilização. Rio de Janeiro: Editora Civilização Brasileira.

Schwartz, S. (1988). Segredos Internos: Engenhos e Escravos na Sociedade Colonial (1550/1835). São Paulo: Companhia das Letras.

Souza, G. (2000). Tratado Descritivo do Brasil em 1587. Recife: Fundação Joaquim Nabuco/Editora Massangana.

Staden, H. (1974 [1557]). Duas viagens ao Brasil. Belo Horizonte/São Paulo: Itatiaia/Edusp.

Subrahmanyan, S. (1997). Connected Histories: Notes toward a Reconfiguration of Early Modern Eurasia. Modern Asian Studies, XXXI (3), 735-762.

Vainfas, R. (1992). Idolatrias luso-brasileiras: as santidades indígenas. En Ronaldo Vainfas (Org.), América em tempo de conquista. Rio de Janeiro: Jorge Zahar.

Varnhagen, F. (1978 [1854]). História Geral do Brasil antes de sua separação e independência de Portugal, 3 Vols. São Paulo: Melhoramentos.

\section{NOTAS}

1. Parafraseando a Walter Benjamin (1986, p. 225).

2. Entre ellos cabe citar los estudios pioneros de Ribeiro (1970) y Hemming (1978), así como otras iniciativas recientes, de naturaleza más didáctica y política; véanse Prezia y Hoonaert (1989); Pacheco de Oliveira y Rocha Freire (2008).

3. Véanse especialmente Carneiro da Cunha (1992) y Ramos y Albert (2002).

4. Debido a su carácter compulsivo, inconsciente y normativo, aquí he preferido llamarla "paradigma".

5. La forma prejuiciosa en que ha sido tratada la historia de los indígenas en el Nordeste (área de la más antigua colonización del Brasil, en la cual los indios fueron considerados "extinguidos" 
desde el siglo XIX tanto por autoridades como por intelectuales) ha limitado bastante los estudios sobre sus manifestaciones culturales, así como el reconocimiento de la agencia indigenista y la adopción de políticas públicas eficientes. Este tema es abordado en una compilación reciente; véase Pacheco de Oliveira (2011).

6. Árbol bastante común en las costas brasileñas durante el siglo XVI, cuyas resinas eran utilizadas para la fabricación de tinturas de color rojizo.

7. Durante el período colonial hasta el siglo XIX sertão indicaba un área con una población reducida y difusa con sistemas económicos rudimentarios, constituyéndose en la antítesis de las capitales y los centros urbanos más desarrollados. Actualmente se refiere a una región semi-árida caracterizada por la baja pluviosidad y, en consecuencia, por vegetación y actividades económicas capaces de resistir la escasez de agua.

8. En portugués, “achamento", sustantivo del verbo "achar", encontrar, hallar (N. de la T.).

9. Véanse algunos estudios importantes realizados en las últimas décadas: Guimarães (1989), Domingues (1989), Guimarães (1995), Cezar (1999 y 2002) y Kodama (2005).

10. Expresión utilizada para una determinada configuración de relaciones de poder entre un conjunto concreto de actores sociales (véase Pacheco de Oliveira, 1988, pp. 54-59; 1999, pp. 8-12).

11. Expresión utilizada por Johannes Fabian (2001, pp. 70-85) para referirse a "una arquitectura de la memoria, posibilitando que alguien cuente historias". Tal idea fue reutilizada por Pacheco de Oliveira (2011, pp. 9-16) para distinguir cuatro modalidades de memorias sobre los indígenas, generando discursos con consecuencias políticas radicalmente distintas.

12. Existe un fuerte antagonismo entre las representaciones positivas de América y las de los indígenas, analizadas por Sérgio Buarque de Holanda (1959) y Stephen Greenblatt (1996), por un lado, y por Laura de Mello e Souza (1993), por el otro. Aunque deben ser entendidas dentro de un mismo imaginario europeo, ellas tuvieron repercusiones muy diferentes en relación a distintos contextos y actividades de colonización, lo cual me ha llevado a optar por referirlas a diferentes situaciones históricas (en las colonias) y a distintos regímenes de memoria sobre los indígenas.

13. Véase Belluzzo (2000).

14. Los viajes, las recepciones y puestas en escena de jefes indígenas en la Europa del siglo XVI (exhibiéndolos tanto exótica como políticamente) y los libros de viajes tuvieron un impacto inmediato sobre el pensamiento europeo; Montaigne habría de inaugurar una genealogía que desembocó en el Iluminismo con Rousseau y la teoría de la bondad natural. Existe una extensa bibliografía sobre este tema, de la cual me limito a citar aquí sólo dos autores, Melo Franco (1976) y Pagden (1982).

15. En portugués, lançados (N. de la T.).

16. "Por ello, me parece que el mejor fruto que podremos obtener [de esta tierra] será salvar a su gente. Tal debe ser la principal semilla que, en ella, Vuestra Alteza debe arrojar.” (Castro 1985, p. 116).

17. Plural de sertão (N. de la T.).

18. En el contexto de la colonización en el Brasil, aldea se refiere a una aglomeración de familias indígenas en un pequeño núcleo poblacional con características urbanas, algunas veces con diferentes lenguas e inclusive enemigas entre sí; las aldeas eran administradas exclusivamente por misioneros que perseguían la catequesis y civilización de los indígenas allí reunidos.

19. Acto administrativo de la Corona Portuguesa por el cual el Rey otorgaba amplios terrenos a determinados súbditos en retribución por un servicio prestado (militar o comercial). Fue el instrumento principal de colonización y de apropiación latifundista en el Brasil. Dado que tales concesiones podían acumularse en las manos de un único señor, las sesmarias marcaron el origen de las grandes haciendas y latifundios.

20. Véase Knauss (1991).

21. Región geográfica que forma un arco alrededor de la Bahia de Todos os Santos, comprendiendo la zona del litoral y el área circundante a la bahía (N. de la T.). 
22. Los datos relativos a la población indígena que serán utilizados aquí se refieren tan solo a los indios "forros" (liberados), residentes en las aldeas misioneras. No existen datos generales relacionados con los indígenas "cautivos", lo cual dificulta enormemente los ejercicios de demografía histórica en el mundo colonial brasileño. Las investigaciones existentes son localizadas, partiendo de inventarios y documentos diversos (en ese sentido véase Monteiro, 1994).

23. Carta de Don Duarte da Costa a Don João III (Salvador da Bahia, 10 de junio de 1555); en Couto (1995, p. 265).

24. Sin embargo, en las narrativas convencionales la proclamación de una "guerra justa" aparece como una reacción inmediata y casi natural provocada por las muertes de aquellos náufragos, sin señalar los años transcurridos entre ambas acciones.

25. Véase la carta de 1532 de Diogo Gouveia a D. João III, de quien era consejero, delineando propuestas sobre la colonización privada del Brasil y la oportunidad de que existieran casamientos entre los naturales del reino y las mujeres indígenas, como forma de acelerar el poblamiento y la multiplicación de vasallos (Couto, 1995, p. 218).

26. Actividad militar y religiosa por medio de la cual familias y comunidades indígenas fueron dirigidas hacia las aldeas administradas por los misioneros. Incluso cuando el objetivo de los descimentos era la captura de esclavos indígenas (en los casos en que existía una declaración oficial de guerra justa, o cuando se trataba de una expedición de «rescate» que debía «liberar» prisioneros que serían víctimas de la antropofagia), era necesaria la presencia de un religioso para verificar si las normas legales estaban siendo respetadas.

27. Véase Raminelli (1996); Lestringant (1997).

28. Moradores particulares, frecuentemente mamelucos (mestizos de portugueses e indios). Debido a su conocimiento de los sertões y de las lenguas y costumbres indígenas, organizaban y dirigían expediciones hacia el interior en busca de metales preciosos y de esclavos indígenas, destinados a las haciendas del litoral.

29. En un estudio reciente y de naturaleza comparativa sobre la economía política del azúcar y la esclavitud negra, Miller demuestra los riesgos de operar con un modelo genérico de plantation esclavista (modelo que propondría una plantation de gran tamaño, especializada y trabajada por esclavos negros). Ese tipo de plantation solo sería viable en contextos históricos muy precisos, siendo los más importantes los emprendimientos económicos en Jamaica y en Santo Domingo durante el siglo XVIII. Fuera de estos casos, es necesario tener ciertos cuidados con la descripción y análisis de fenómenos aparentemente semejantes, dado que algunos factores económicos, demográficos y políticos pueden transformar tales iniciativas "en una entidad completamente diferente a la de sus precedentes" (Miller, 1997, p. 12).

30. Es importante aprehender estos datos sin caer en la trampa creada por la visión indigenista que será criticada más adelante, polarizada entre exterminio y protección. A pesar de las fugas (individuales o de grupos familiares) y de los movimientos migratorios hacia las áreas del sertão, los indígenas del litoral continuarán viviendo en las aldeas, tomándolas como un punto de convergencia y referencia hasta por lo menos la segunda mitad del siglo XIX.

31. Véase Pacheco de Oliveira (2004, pp. 39-42).

32. FUNAI, Fundación Nacional del Índio, agencia indigenista oficial; FUNASA, Fundación Nacional de Salud; MEC, Ministerio de la Educación; MMA, Ministerio del Medio Ambiente; ONG, organizaciones no gubernamentales.

33. Véase Vainfas (1992).

34. Hecho que genera desconfianza en la mayoría de los brasileños, tanto en lo que concierne a los procesos de etnogénesis como también en relación a los intelectuales y líderes indígenas que expresan un discurso político autónomo y articulado.

35. Véase Mendes Jr. (1912); Gambini (1999). 
36. Conviene tener presente que el autor estaba refiriéndose al contexto republicano, cerca de medio siglo después de la libertad de los esclavos.

37. Recibe este nombre compuesto la residencia patronal en los ingenios de azúcar (N. de la T.).

38. Véase Pacheco de Oliveira (2000; 2013).

\section{RESÚMENES}

Este artículo propone una relectura "a contrapelo" de los eventos relacionados con el inicio de la fundación de la colonia Brasil en el siglo XVI, interpretándolos bajo la perspectiva del establecimiento del dominio portugués sobre las poblaciones autóctonas de la costa atlántica de América del Sur. Con una mirada historiográfica, realiza una revisión crítica de categorías coloniales, imágenes e interpretaciones reificadas sobre los indios y el Brasil, haciendo estallar una estructura narrativa que impide comprender los hechos en la época en que sucedieron y obstaculiza la investigación científica actual en Antropología e Historia. Este reexamen del pasado permite colocar bajo otra luz los procesos orientados hacia la dominación y el control de nuevas tierras y poblaciones, indicando -en una perspectiva de larga duración- el papel crucial que ocupa la expansión de la frontera interior para la construcción del país, así como para la definición de sus prácticas y categorías administrativas y de autoentendimiento. La comprensión de las movilizaciones indígenas contemporáneas y de los procesos de etnogénesis registrados actualmente en el Nordeste brasileño constituyen una fuente crucial de inspiración para el ejercicio historiográfico aquí realizado.

This paper proposes a new reading "against the grain" of the events related with the founding of the Brazil colony in the sixteenth century, interpreting them from the perspective of the establishment of Portuguese domination of the indigenous peoples of the Atlantic coast of South America. With a historiography approach, it provides a critical review of colonial categories, reified images and interpretations about the Indians and Brazil, dismantling a narrative structure that prevents the understanding of the facts at the time of their occurrence and hampers current scientific research in Anthropology and History. This review of the past allows to place in a different light those processes oriented towards domination and control of new lands and populations, indicating, on a long-term perspective, the crucial role that inner frontier expansion plays for the construction of the country, and for the definition of their practices and administrative categories and self-understanding. Understanding the contemporary indigenous mobilizations and ethnogenesis processes currently registered in the Brazilian Northeast are a crucial source of inspiration for the historiography exercise conducted here.

\section{ÍNDICE}

Keywords: Natives, Nation building, historiography, Pacification, Protection / extermination, Ethnic and racial classifications, Processes of frontier occupation

Palabras claves: Indígenas, Nation building, Pacificación, Protección/exterminio, Clasificaciones étnicas y raciales, Procesos de ocupación de fronteras interiores. 


\section{AUTORES}

\section{JOÃO PACHECO DE OLIVEIRA}

Museu Nacional UFRJ Programa de Pós-Graduação em Antropologia Social, Brasil. Correo electrónico: jpo.antropologia@gmail.com 